\title{
Hybrid Mn-Porphyrin-Nanogold Nanomaterial Applied for the Spectrophotometric Detection of $\beta$-Carotene
}

\author{
Anca Lascu (D), ${ }^{1}$ Mihaela Birdeanu, ${ }^{2}$ Bogdan Taranu, ${ }^{2}$ and Eugenia Fagadar-Cosma ${ }^{1}$ \\ ${ }^{1}$ Institute of Chemistry Timisoara of Romanian Academy, M. Viteazul Ave. 24, 300223 Timisoara, Romania \\ ${ }^{2}$ National Institute for Research and Development in Electrochemistry and Condensed Matter, 1 Plautius Andronescu Street, \\ 300224 Timisoara, Romania \\ Correspondence should be addressed to Anca Lascu; ancalascu@yahoo.com
}

Received 26 January 2018; Revised 17 April 2018; Accepted 29 April 2018; Published 30 May 2018

Academic Editor: Artur M. S. Silva

Copyright (c) 2018 Anca Lascu et al. This is an open access article distributed under the Creative Commons Attribution License, which permits unrestricted use, distribution, and reproduction in any medium, provided the original work is properly cited.

\begin{abstract}
A hybrid formed between $\mathrm{Mn}(\mathrm{III})$ tetratolyl-porphyrin chloride $(\mathrm{MnTTPCl})$ and spherical gold colloid $(n-A u), M n T T P C l / n-A u$, was tested along with its component nanomaterials as promising candidates in the detection of $\beta$-carotene from ethanol solutions. Among the investigated nanomaterials, the largest $\beta$-carotene concentration interval detectable by UV-Vis spectrophotometry $\left(9.80 \times 10^{-6} \mathrm{M}-1.15 \times 10^{-4} \mathrm{M}\right)$ was obtained when using the $\mathrm{MnTTPCl} / \mathrm{n}-\mathrm{Au}$ hybrid. This hybrid material gives rise to the widest absorption band, covering the range of $425 \mathrm{~nm}$ to $581 \mathrm{~nm}$ after treatment with $\beta$-carotene.
\end{abstract}

\section{Introduction}

The presumed antioxidant properties of $\beta$-carotene are well promoted [1], but previous studies show that the beneficial effect of supplementary $\beta$-carotene intake is not convincingly proven either for porphyria [2] or for diabetes prevention [3]. The average intake dosage of $\beta$-carotene as food additive is about $1-2 \mathrm{mg} \cdot$ person $^{-1} \cdot$ day $^{-1}$ [4].

The protective effect of $\beta$-carotene against DNA mutations in the case of prolonged UVA (the longest of the three nonvisible electromagnetic wavelengths that come from the Sun, at 320-400 nanometers) exposure was documented [5]. Studies regarding the risk of age-related macular degeneration suggest that carotenoids $[6,7]$ have a beneficial preventing effect, but the authors agree that the results are controversial. Patients with rheumatoid arthritis present decreased levels of $\beta$-carotene, antioxidant vitamins, and enzymes in plasma and are subjected to oxidative stress [8].

In order to minimize oxidative stress in patients with cystic fibrosis, a supplement of $1 \mathrm{mg}$ beta-carotene $\mathrm{kg} \cdot \mathrm{BW}^{-1}$. day ${ }^{-1}$ (maximally $50 \mathrm{mg} \beta$-carotene day ${ }^{-1}$ ) leads to the improvement of the quality of life [9].
This vitamin A precursor is not synthesized by animal tissue and must be provided from diet or supplements. Nevertheless, the right amount of intake is not yet determined, an excess might lead to carotenosis, when the skin turns orange by the deposition of carotenoids in the outer layer of epidermis [10]. In some cases, such as heavy smokers, it was established that higher concentrations of $\beta$-carotene in the system can act as prooxidants, especially in the oxygenated tissues like the lungs, and can favor the incidence of cancer [11]. High doses of $\beta$-carotene can also determine the proliferation of prostate cancer cells [12]. Meanwhile, it was concluded that excessive amount of vitamin $\mathrm{A}$ in pregnant females is linked to birth defects like heart deformities and eye and lung diseases of the fetus [13].

Numerous molecules present in natural or dietary products (carotenoids, polyphenol oligomers, and epicatechin) can act as scavengers and neutralizers of peroxynitrite, although their in vivo peroxynitrite neutralizing activity is low [14].

Taking into account this controversial benefic effect, the demand to accurately detect $\beta$-carotene became compulsory.

The water-insoluble carotenoids are transported by lowdensity lipoproteins through blood and can be detected in 
plasma or serum using high-pressure liquid chromatography (HPLC) [15]. Human blood plasma carotenoids were also comparatively detected after extraction by using HPLC [16], fluorimetric detection, UV detection, and electrochemical detectors. It was concluded that the electrochemical method is the most efficient one, using high applied voltage.

Another HPLC method for the determination in plasma of vitamin $\mathrm{C}$, vitamin $\mathrm{E}$, and $\beta$-carotene levels was associated with photodiode array detection [17]. In the particular case of $\beta$-carotene, measuring at the wavelength of $400 \mathrm{~nm}$, the detection limit was $0.25 \mathrm{mg} \cdot \mathrm{mL}^{-1}$.

For the detection of $\beta$-carotene, from very small blood samples $(200 \mu \mathrm{L})$ [18], an HPLC method using multiwavelength detection was also successfully applied.

In the case of determining the content of carotenes in cooked food, a coupled HPLC method was employed [19] with UV-Vis spectrophotometric detection at the wavelength of $470 \mathrm{~nm}$. Lycopene and $\beta$-carotene were detected in bakery products [20] by high-performance liquid chromatography with diode array and atmospheric pressure chemical ionization-mass spectrometry detection (HPLCDAD-APCI-MS).

For simultaneous determination of anthocyanoside and $\beta$-carotene in pharmaceutical preparations [21], a thirdderivative function of the ultraviolet spectrophotometry method using the zero-crossing technique was used. The technique could detect as little as $6.25 \mu \mathrm{g} \cdot \mathrm{mL}^{-1} \beta$-carotene without interferences.

Raman spectroscopy was used for the detection of $\beta$-carotene and lycopene concentrations in living human skin, based on the changes of fingerprint carbon-carbon double bond stretch vibrations. The method allows rapid screening of carotenoid compositions in a noninvasive fashion and contributes to risk assessment in cutaneous diseases [22, 23].

FT-IR and Raman spectroscopy were used for the rapid determination of bacterial carotenoids in soil [24]. Raman microspectrometry was used to detect $\beta$-carotene up to $0.25 \mathrm{mg} \cdot \mathrm{kg}^{-1}$ in mixtures of polyaromatic hydrocarbons and usnic acid for the purpose of investigating Martian soil [25] with light equipment.

Manganese porphyrins appear to be the most suitable for recognition of biologically active compounds (histamine, dopamine, and glucose) $[26,27]$ due to the high ability to form metal-ligand bonds and to alter the metal-centered redox potential, along with the distortion of planar structure.

Manganese(III) complex of 5,10,15,20-tetrakis(pentafluorophenyl)porphyrin and gold nanoparticles deposited on fluorine tin oxide- (FTO-) coated glass electrodes were successfully used in the amperometric sensing of cysteine [28].

The rich self-assembling possibilities of hybrid plasmonic couples due to structural plasticity of porphyrin molecules lead to achieving the required optical properties to be used in plasmonic sensing of vitamins and pharmaceutical compounds [29].

Based on our previous experience concerning the sensing capacity of hybrid nanomaterials formed between porphyrins and nanosized noble metals [30-32], the present work focuses on obtaining and investigating the hybrid

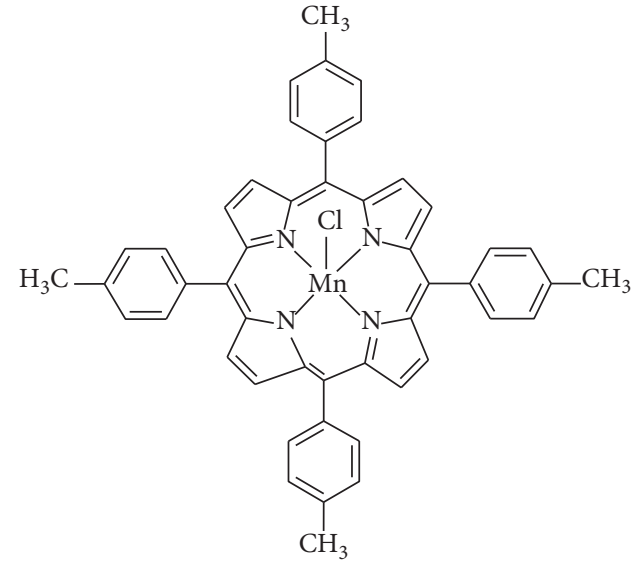

(a)

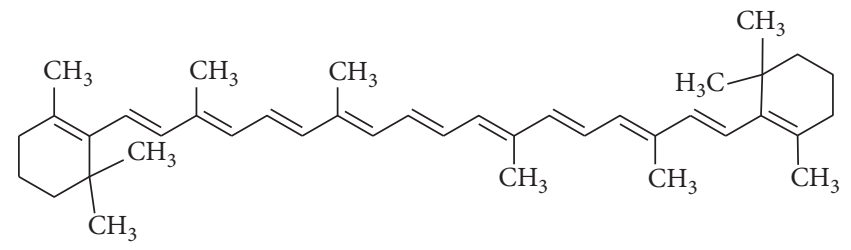

(b)

FIGURE 1: Structure of chloro[5,10,15,20-tetrakis-(4-methylphenyl) porphyrinato manganese(III)] ( $\mathrm{MnTTPCl}$ ) (a) and $\beta$-carotene (b).

$(\mathrm{MnTTPCl} / n-\mathrm{Au}) \mathrm{UV}$-Vis response toward $\beta$-carotene in ethanol solutions (Figure 1). A comparative study of the optical detecting capacity of this hybrid's components including chloro [5,10,15,20-tetrakis-(4-methylphenyl)porphyrinato manganese (III)] (MnTTPCl) and bare gold nanoparticles $(n-A u)$ was also performed.

\section{Materials and Methods}

Chloro[5,10,15,20-tetrakis-(4-methylphenyl)porphyrinato manganese(III)] ( $\mathrm{MnTTPCl}$ ) was prepared from the corresponding porphyrin base, which was previously reported and fully characterized [33], by using classical metallation of the porphyrin-free ligand (in ethanol at porphyrin: manganese ratios of $1: 20-1: 30$ ) [34]. The FT-IR, Raman, UV-Vis, and fluorescence spectroscopic data and AFM, SEM, TEM, and electrochemical characterizations of $\mathrm{MnTTPCl}$ were reported in already published papers [35] together with some specific characterizations for sensing applications of diclofenac, $\mathrm{H}_{2} \mathrm{O}_{2}$, and $\mathrm{NO}_{2}$ gas $[32,36]$; $\beta$-carotene was purchased from Merck, and the gold colloid was synthesized according to recent literature data [37] and already characterized by UV-Vis, AFM, TEM, and STEM [31, 38]. The solvents used were purchased from Merck (THF) and Chemopar (ethanol).

UV-visible spectra were registered on a JASCO model V-650 spectrometer in $1 \mathrm{~cm}$ quartz cuvettes. A Nanosurf ${ }^{\circledR}$ EasyScan 2 Advanced Research AFM (Switzerland) microscope was used for registering atomic force microscopy (AFM). The samples were deposited from solvent mixtures (THF/water/ethanol in different ratios) onto pure silica plates, and the surface imaging 


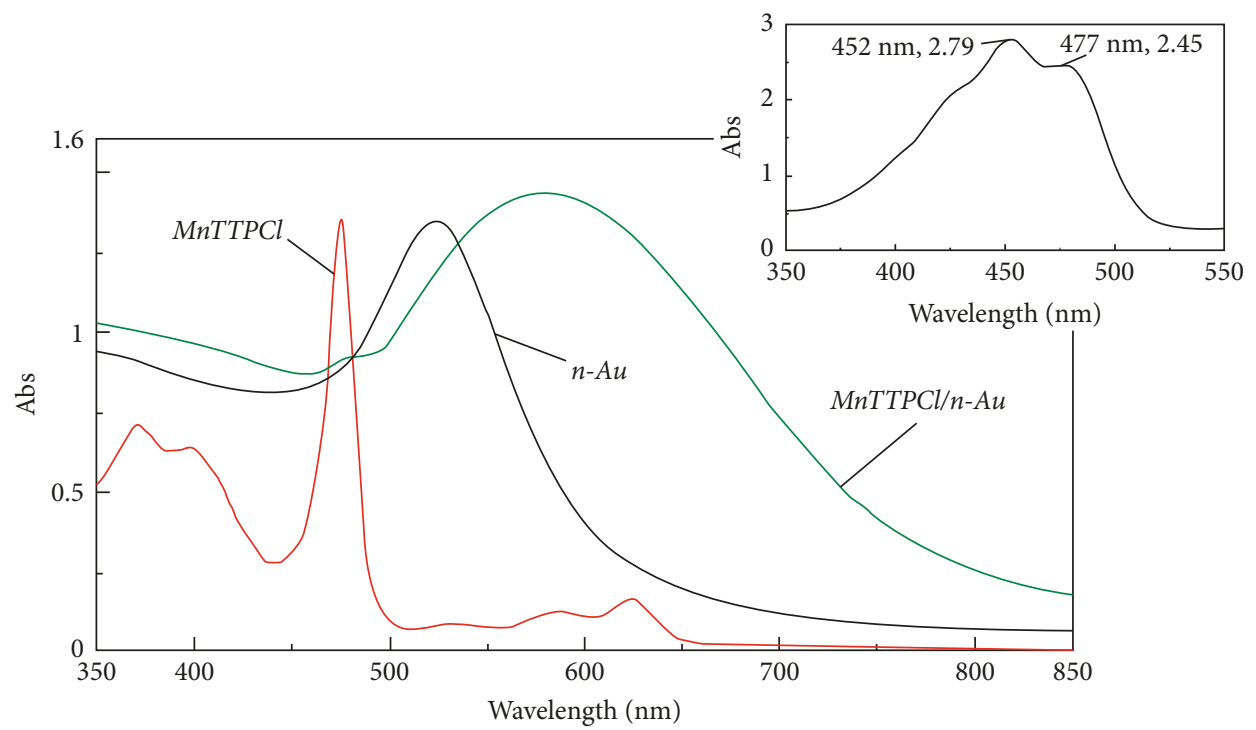

FigURE 2: The superposed UV-Vis spectra of the nanomaterials (a). Detailed UV-Vis spectrum of the $\beta$-carotene solution $\left(c=5 \times 10^{-4} \mathrm{M}\right)$ in ethanol (b).

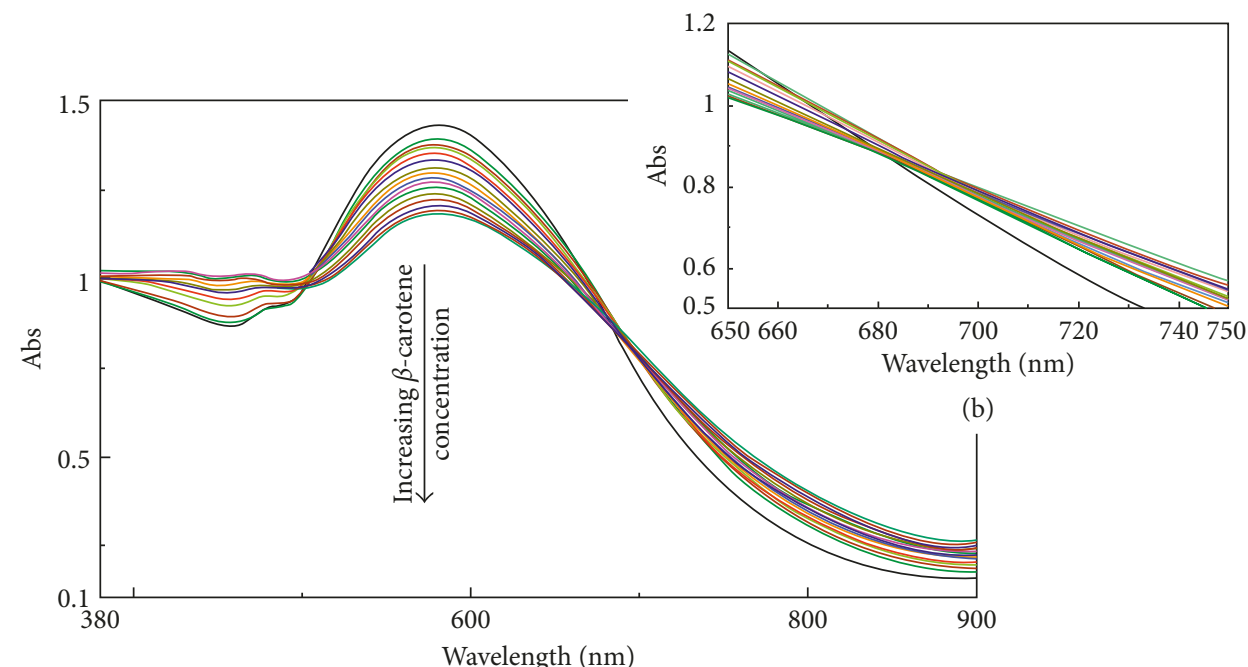

(a)

FIgURE 3: Overlapped UV-Vis spectra of the successive adding of $\beta$-carotene solution to the $M n T T P C l / n$ - $A u$ hybrid (a). Details of the isosbestic point at $685 \mathrm{~nm}$ (b).

was performed at room temperature. AFM images were obtained in the noncontact mode.

A Titan G2 80-200 TEM/STEM microscope (FEI Company, Netherlands) was used to record STEM and TEM images at $200 \mathrm{kV}$ for samples prepared on 200 mesh carboncoated copper grids. The TEM and STEM images were obtained using Digital Micrograph v. 2.12 and TEM Imaging \& Analysis V. 4.7 software.

\subsection{Experimental}

2.1.1. Formation of the $M n T T P C l / n-A u$ Hybrid. A hybrid between $\mathrm{MnTTPCl}$ and gold colloid $n$-Au $(\mathrm{MnTTPCl} / n-\mathrm{Au})$ was prepared as previously published [32]: a solution of
$0.5 \mathrm{~mL} \mathrm{MnTTPCl}$ in THF $\left(c=1.1 \times 10^{-6} \mathrm{M}\right)$ (Figure 2) is added under stirring to $6 \mathrm{~mL}$ solution of gold colloid in water $\left(c=4.58 \times 10^{-4} \mathrm{M}\right)$.

This ratio between components was chosen due to the fact that it gives rise to the broadest and most intense plasmonic band.

The superposed UV-Vis spectra as presented in Figure 2 showed the differences between the $\mathrm{MnTTPCl}$ spectrum, the plasmonic spectrum of gold colloid solution in water, and the wide plasmonic band of the $M n T T P C l / n-A u$ hybrid. The detail represents the UV-Vis spectrum of the $\beta$-carotene solution in ethanol. The major peak of Mn-porphyrin is located at $477 \mathrm{~nm}$, the highest intensity of the gold plasmon is positioned at $525 \mathrm{~nm}$, and the plasmonic band of the $\mathrm{MnTTPCl} / \mathrm{n}$-Au hybrid 


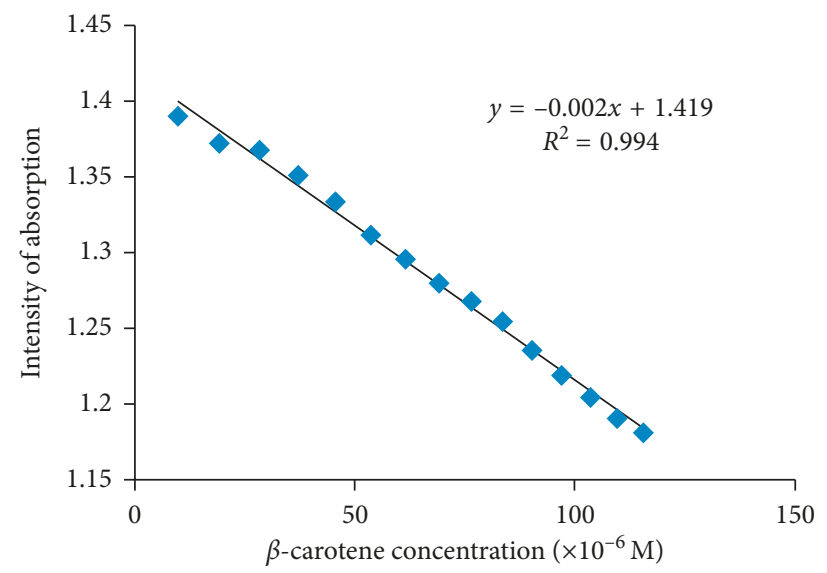

Figure 4: The dependence between the intensity of absorption of the hybrid plasmon and the $\beta$-carotene concentration.

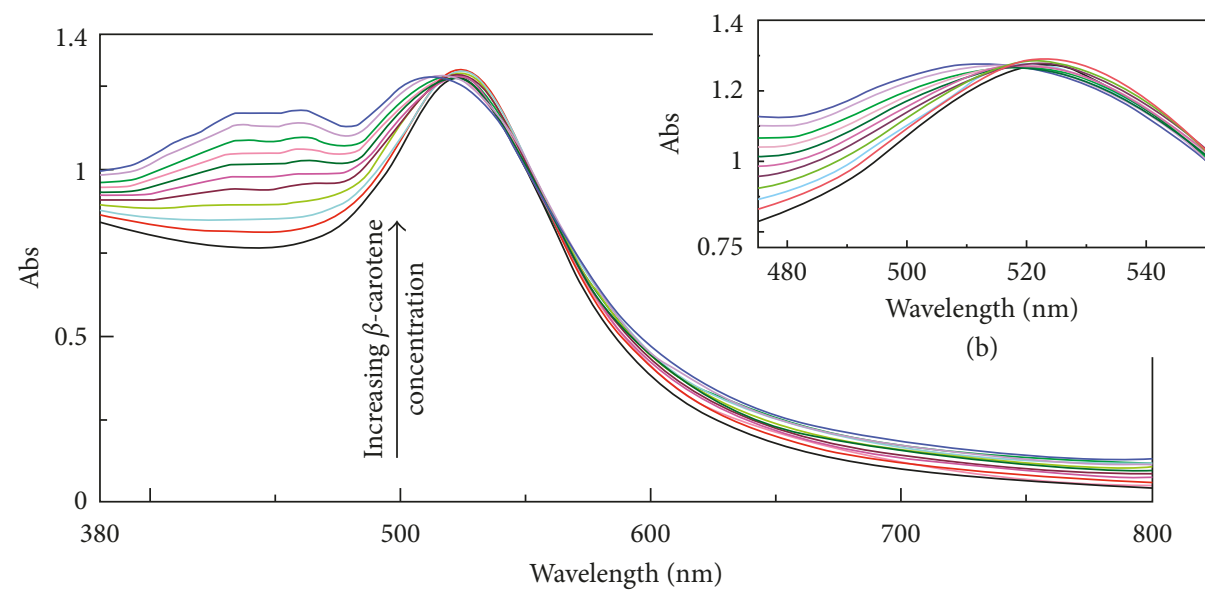

(a)

Figure 5: Overlapped UV-Vis spectra for adding $\beta$-carotene solution to gold colloid solution (a). Details of the isosbestic point at $515 \mathrm{~nm}(\mathrm{~b})$.

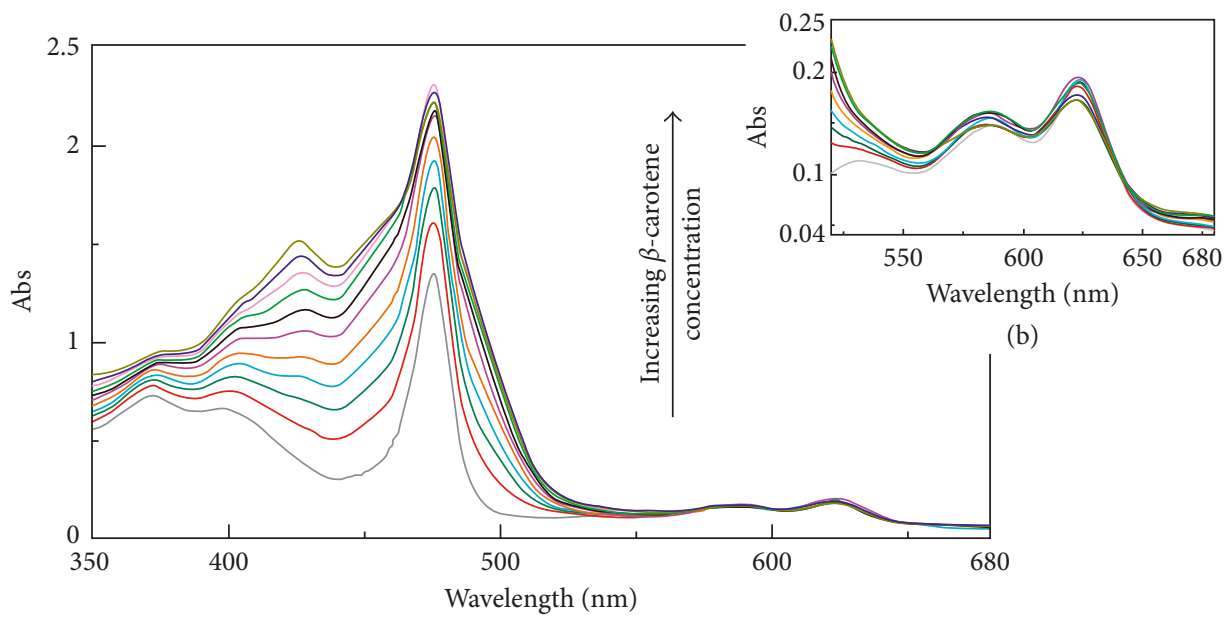

(a)

Figure 6: Overlapped UV-Vis spectra for the detection of $\beta$-carotene solution in ethanol by $M n T T P C l$ solution in THF (a). Details of the isosbestic point at $645 \mathrm{~nm}$ (b). 


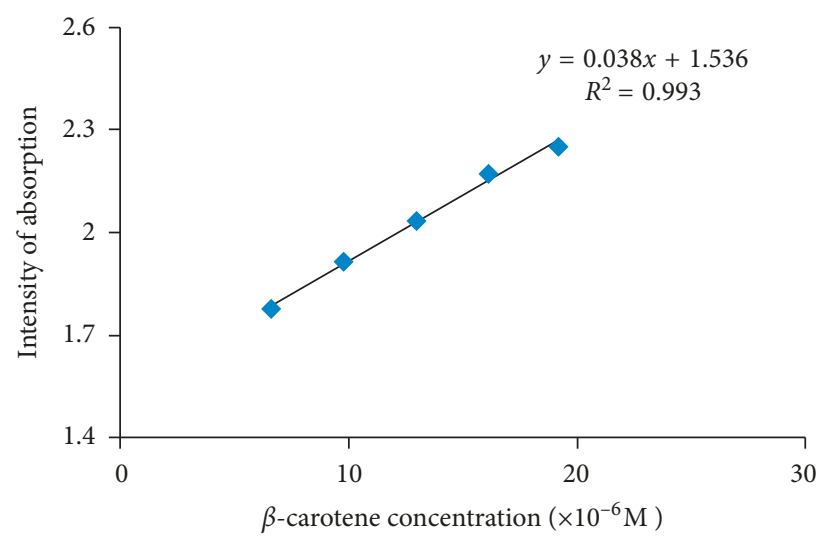

FIGURE 7: Dependence between the Soret band intensity of the $M n T T P C l$ solution and $\beta$-carotene concentration.

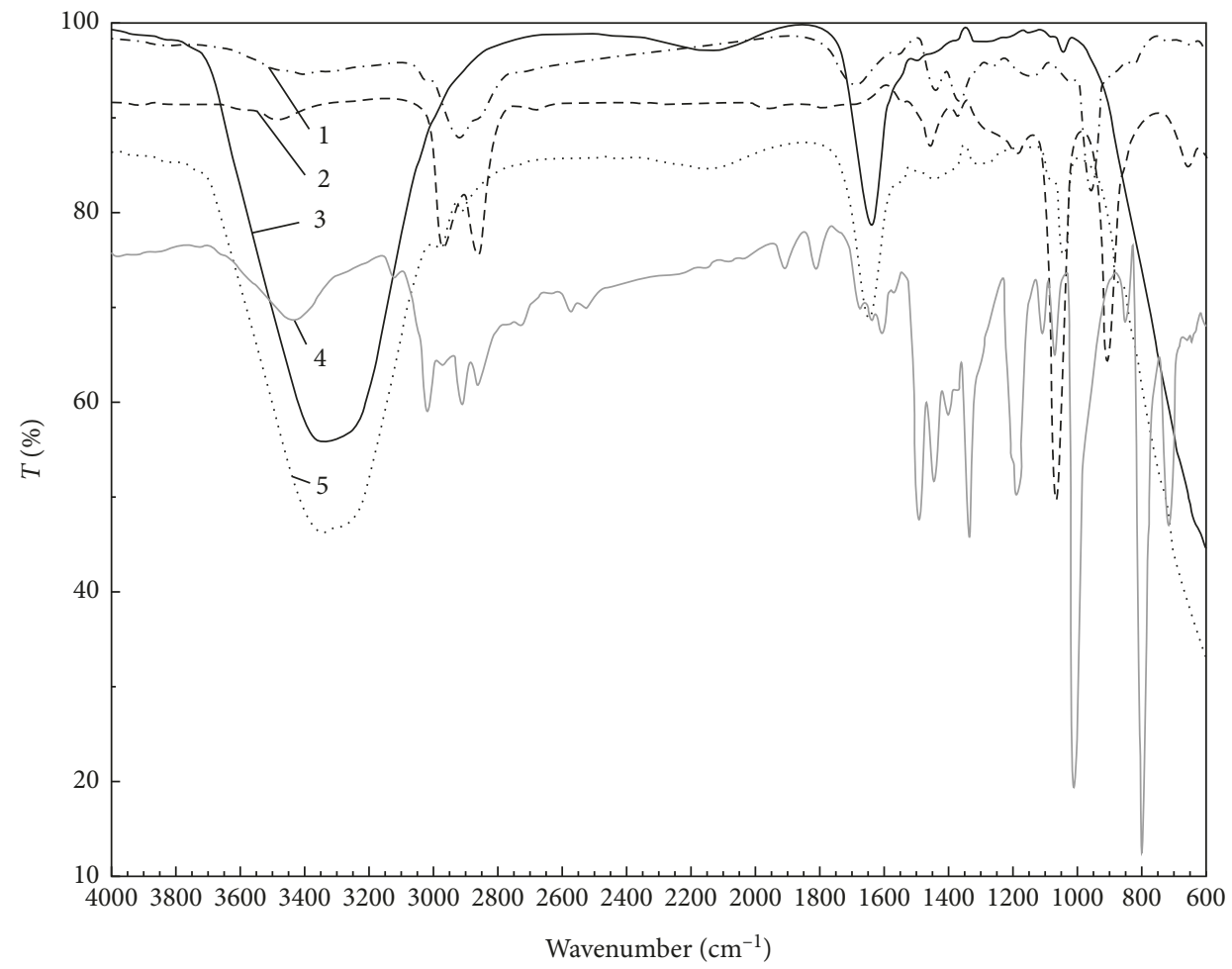

FIGURE 8: Overlapped IR spectra: $\beta$-carotene (line 1); $M n$ TTPCl treated with $\beta$-carotene (line 2); $n$ - $A u$ treated with $\beta$-carotene (line 3); $\mathrm{MnTTPCl}$ (line 4); $\mathrm{MnTTPCl} / \mathrm{n}$-Au treated with $\beta$-carotene (line 5).

is strongly bathochromically shifted to $590 \mathrm{~nm}$, widening in the wavelength range of $480-750 \mathrm{~nm}$ and manifesting a hyperchromic effect. These three features of the hybrid nanomaterial recommend it for optoelectronic applications [39].

2.1.2. The $\beta$-Carotene Detection. To $5 \mathrm{~mL}$ of each investigated solution of fixed concentration $(\mathrm{MnTTPCl} / n-\mathrm{Au}$ or $\mathrm{MnTTPCl}$ or $n-\mathrm{Au}), 0.100 \mathrm{~mL} \beta$-carotene solution in ethanol $\left(c \times 10^{-6} \mathrm{M} ; c=1.99 ; 3.96 ; 5.92 ; 7.87 ; 9.80 ; 19.23\right.$; 28.30 ; 37.03; 45.45; 53.57; 61.40; 68.96; 76.27; 83.33; 90.16; $96.77 ; 103.31 ; 109.37 ; 115.38)$ is successively added. After 30 seconds of vigorous stirring at room temperature, the UVVis spectra are recorded for each step.

\section{Results and Discussions}

3.1. UV-Vis Analysis regarding the Influence of $\beta$-Carotene on the Sensitive Materials: $\mathrm{MnTTPCl} / n-\mathrm{Au}$ or $\mathrm{MnTTPCl}$ or $n$ - $A$ u

3.1.1. MnTTPCl/n-Au Hybrid Solution Treated with $\beta$-Carotene. Analyzing the overlapped spectra (Figure 3), it can be concluded that the increase in $\beta$-carotene concentration that 

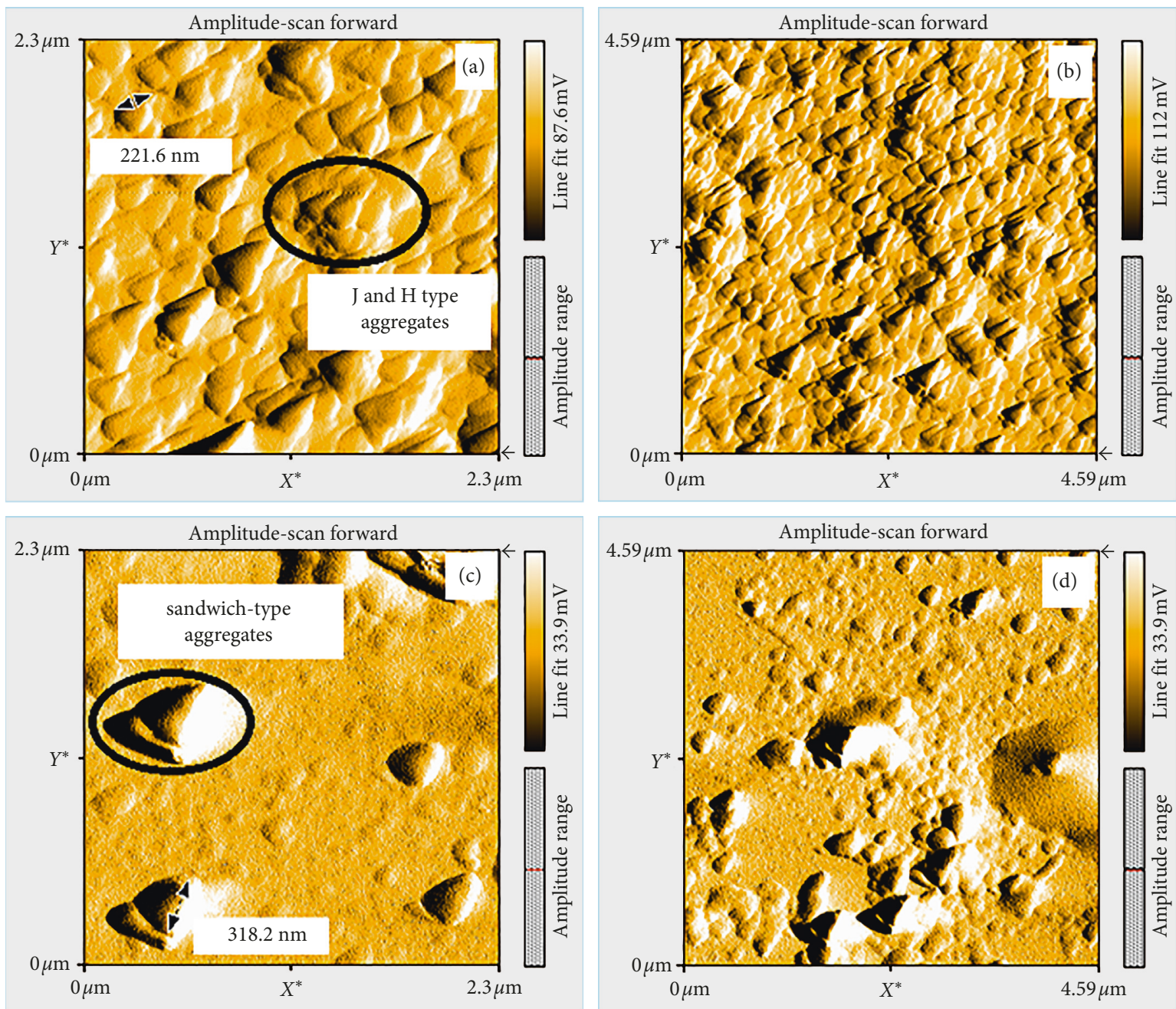

Figure 9: AFM images for the $M n T T P C l / n$ - $A u$ hybrid before $(a, b)$ and after treatment with $\beta$-carotene (c, d).

is added to the $M n T T P C l / n$ - $A u$ hybrid solution leads to the decrease in intensity of the plasmonic band. One clear isosbestic point that is observed at $685 \mathrm{~nm}$ (Figure 3(b)) proves that the phenomenon is due to some equilibrium processes leading to the formation of chemical intermediates between $\beta$-carotene and the $\mathrm{MnTTPCl} / n$ - $\mathrm{Au}$ hybrid. The dependence between the absorption intensity of the plasmon and the $\beta$-carotene concentration is linear (Figure 4 ) with an excellent correlation coefficient of $99.4 \%$. The $\beta$-carotene concentration domain for which the $\mathrm{MnTTPCl} / n-\mathrm{Au}$ hybrid is able to detect the antioxidant molecule is quite large, ranging two orders of magnitude. The lowest concentration of detected $\beta$-carotene is $9.804 \times 10^{-6} \mathrm{M}$, and the highest is $1.1538 \times 10^{-4} \mathrm{M}$.

3.1.2. Nano-Au Treated with $\beta$-Carotene. As can be seen in Figures 5(a) and 5(b), the plasmon intensity decreases with the increase in $\beta$-carotene concentration and discretely shifts to lower wavelengths $(523 \mathrm{~nm}$ for the $\beta$-carotene concentration of $9.804 \times 10^{-6} \mathrm{M}$ and $518 \mathrm{~nm}$ for the concentration of $\beta$-carotene of $\left.6.1403 \times 10^{-5} \mathrm{M}\right)$. Two isosbestic points are detectable, at $515 \mathrm{~nm}$ (Figure 5(b)) and $556 \mathrm{~nm}$, respectively, indicating the formation of a certain complex between $\beta$-carotene and gold nanoparticles. As a conclusion, the gold nanoparticles investigated in this shape and size cannot detect $\beta$-carotene in this range of concentrations with accurate sensitivity.

3.1.3. MnTTPCl Treated with $\beta$-Carotene. It can be observed that the increase in $\beta$-carotene concentration leads to the increase in the intensity of the absorption of the Soret band (Figure 6). Nevertheless, after a certain concentration in $\beta$-carotene $\left(2.2 \times 10^{-5} \mathrm{M}\right)$, the solution registers a twist and the intensity of absorption remains constant or even decreases beyond. An isosbestic point is detectable at $645 \mathrm{~nm}$ on the last $\mathrm{Q}$ band of the porphyrin (Figure 6(b)).

The maximum $\beta$-carotene concentration detectable in a linear fashion by the MnTTPCl solution is $1.92 \times 10^{-5} \mathrm{M}$ (Figure 7). The detected $\beta$-carotene concentration is in the range of $6.58 \times 10^{-6} \mathrm{M}-1.92 \times 10^{-5} \mathrm{M}$. This domain is narrower than the one detected by the $\mathrm{MnTTPCl} / \mathrm{n}$-Au hybrid solution. 

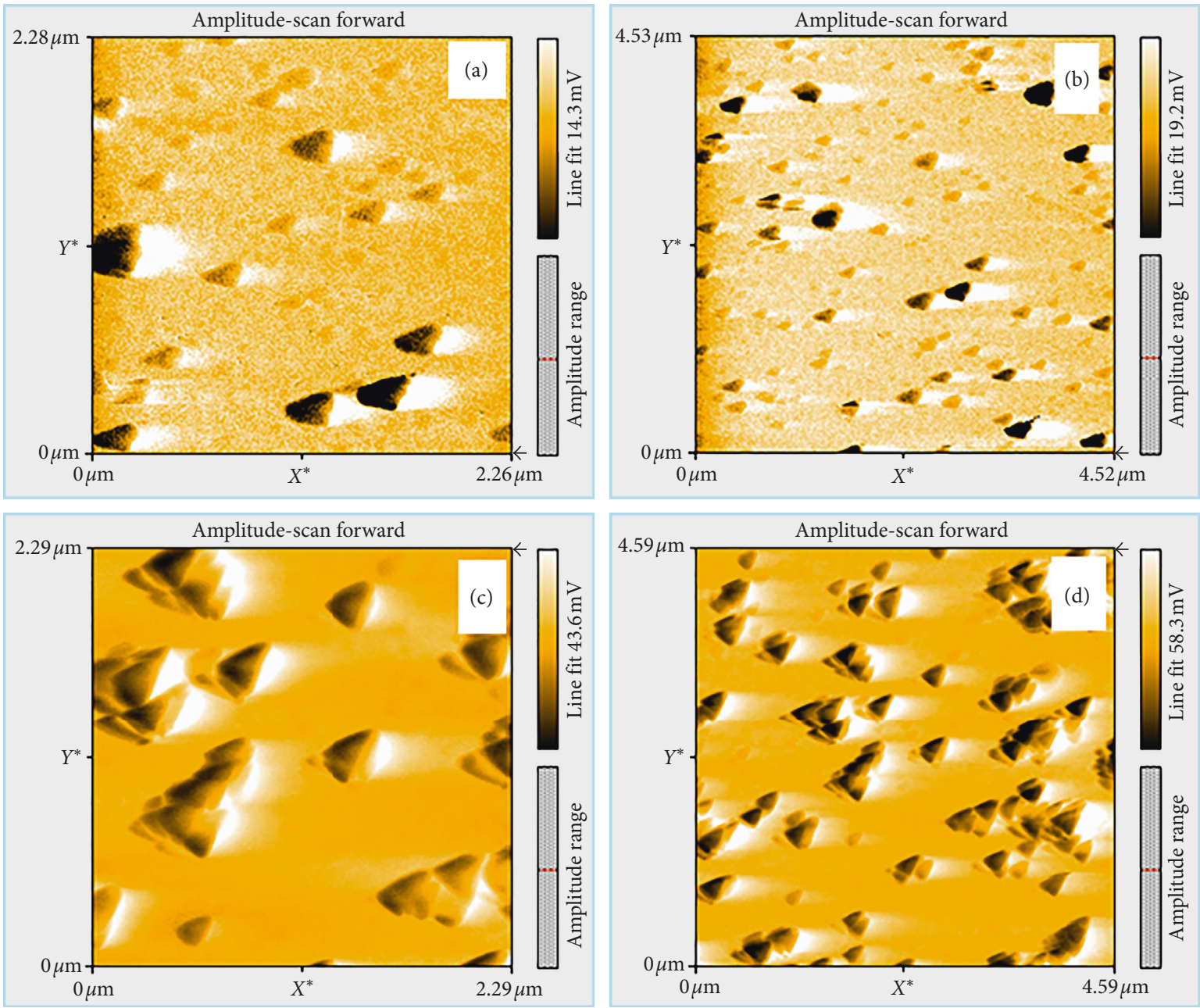

Figure 10: AFM images for $n$ - $A u$ before $(a, b)$ and after treatment with $\beta$-carotene $(c, d)$.

3.2. FT-IR Analysis. In the FT-IR spectrum of $\beta$-carotene (Figure 8, line 1), the alkenyl $\mathrm{C}=\mathrm{C}$ streching bonds can be identified at $1620-1680 \mathrm{~cm}^{-1}$ [24], and the peaks above $3000 \mathrm{~cm}^{-1}$ are indicative of unsaturated chains. In the case of $\mathrm{MnTTPCl}$ treated with $\beta$-carotene (Figure 8, line 2 ), the FT-IR spectrum contains the corresponding bands for C-H aliphatic bonds at $2861 \mathrm{~cm}^{-1}$ and $2967 \mathrm{~cm}^{-1}$, as well as the absorption band at $906 \mathrm{~cm}^{-1}$ characteristic for $\mathrm{C}-\mathrm{H}$ vinyl-substituted bonds. In the spectrum of the gold colloid treated with $\beta$-carotene (Figure 8, line 3), the weak absorption band at $1043 \mathrm{~cm}^{-1}$ could be attributed to the $\mathrm{CH}_{3}$ bond rocking from $\beta$-carotene. In the spectra of the materials treated with $\beta$-carotene (Figure 8 , lines 2,3 , and 5 ), there are common features such as the enlargement of the $\mathrm{O}-\mathrm{H}$ bands from 3300 to $3400 \mathrm{~cm}^{-1}$ (Figure 8, lines 3, 5) as well as the characteristic band around $1060 \mathrm{~cm}^{-1}$ that can be attributed to manganese-porphyrin $\delta \mathrm{C}-\mathrm{H}$ bonds [35] from pyrrole and from phenyl (Figure 8, curves 2 and 5).

3.3. AFM Analysis. The AFM images of the $M n T T P C l / n-A u$ hybrid show a significant change of the aggregation process after being exposed to $\beta$-carotene. In the case of the bare hybrid (Figures 9(a) and $9(\mathrm{~b})$ ), triangule-shaped structures having average dimensions of $278.2 \mathrm{~nm}$ are further aggregated by both J-type and H-type processes to form ordered oriented rows. Finally, an organized multilayer composed of triangular bricks is formed.

In the case of the $M n T T P C l / n-A u$ hybrid exposed to $\beta$-carotene (Figures 9(c) and 9(d)), the dimension of the aggregates slightly increased to $318.2 \mathrm{~nm}$ (Figure 9(c)) and the number of assembled molecules diminished. It can be concluded that both J- and $\mathrm{H}$-type aggregation processes are scarcer than those in the case of the bare nanomaterial. In the map in shadows for $4 \mathrm{~nm}$ (Figure 9(d)), it can be observed that the aggregates of the hybrid treated with $\beta$-carotene form pyramid-like or conical superstructures with an average height distribution of $21 \mathrm{~nm}-50 \mathrm{~nm}$. Besides, some kvataron-shaped structures [40] are visible (Figure 9(c)).

Anisometric nanoparticles of gold (Figures 10(a) and 10(b)) have generated significant interest since they can display various properties as a function of orientation [41]. Under the influence of $\beta$-carotene, the gold nanoparticles $(n-A u)$ (Figures $10(\mathrm{c})$ and $10(\mathrm{~d}))$ aggregate into triangles 

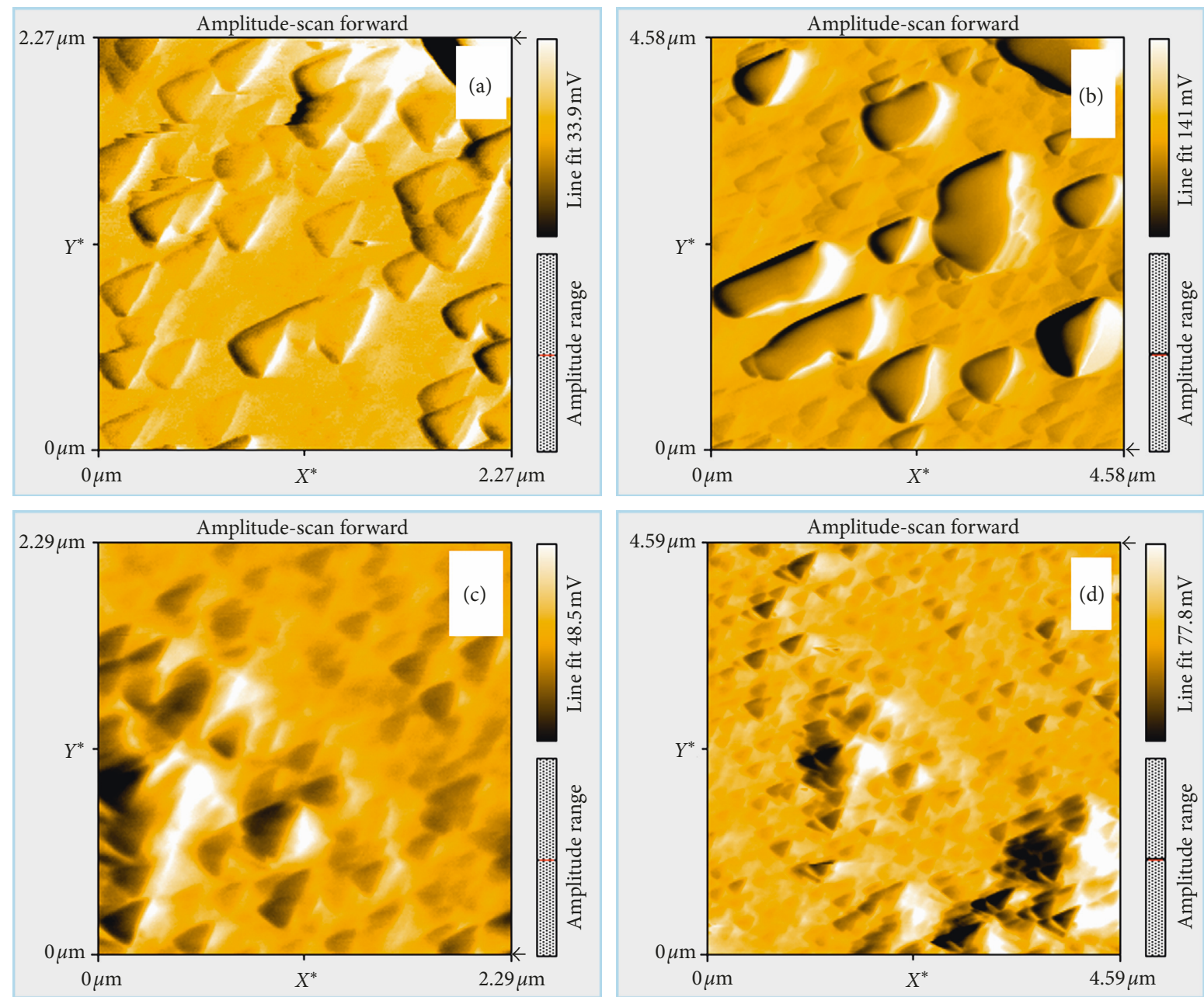

Figure 11: AFM images for $\operatorname{MnTTPCl}$ before $(\mathrm{a}, \mathrm{b})$ and after exposure to $\beta$-carotene (c, d).

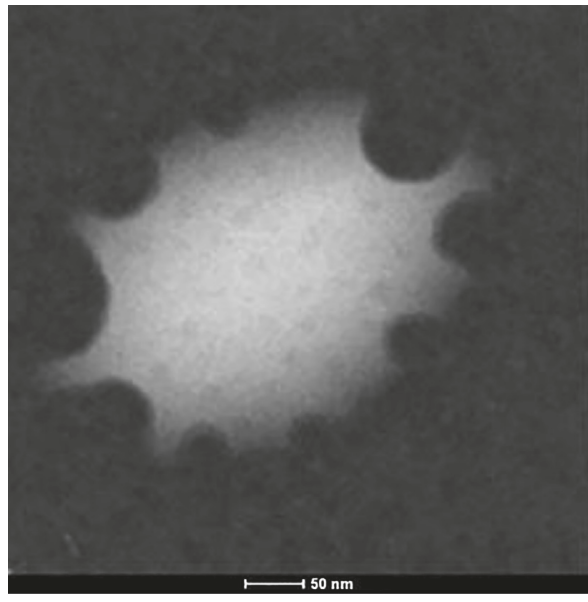

(a)

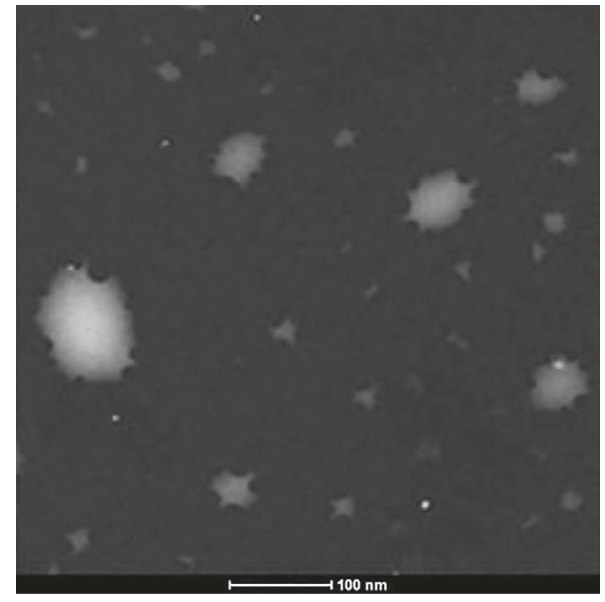

(b)

FIGURE 12: STEM images for $M n T T P C l / n$ - $A u$ hybrid treated with $\beta$-carotene.

varying in dimensions between $192.4 \mathrm{~nm}$ and $268.6 \mathrm{~nm}$. These triangles further agglomerate into linked structures having an average height distribution of $12.9 \mathrm{~nm}-22 \mathrm{~nm}$.
Under the influence of $\beta$-carotene, the $\mathrm{MnTTPCl}$ generates inhomogeneous layers (Figures 11(c) and 11(d)), manifesting the same behavior as the MnTTPCl/n-Au hybrid and $n-A u$. 


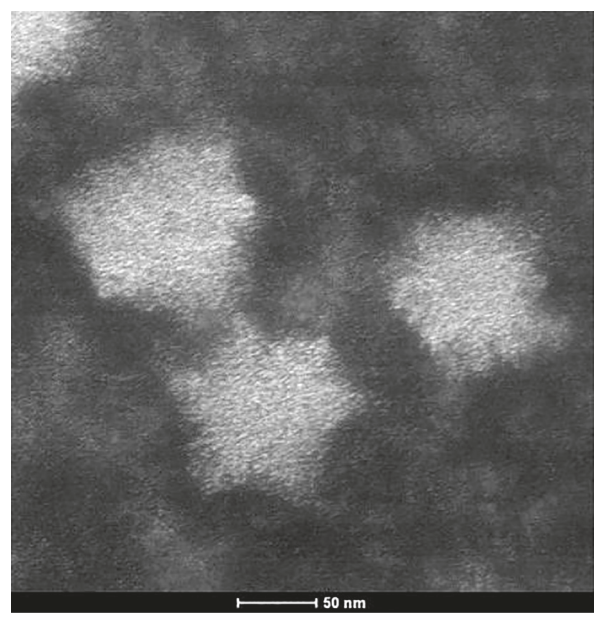

(a)

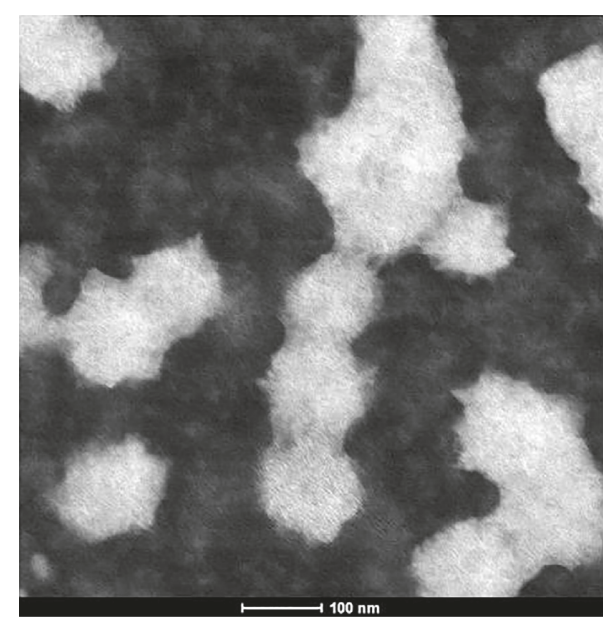

(b)

FIGURE 13: STEM images recorded for $M n T T P C l$ treated with $\beta$-carotene.
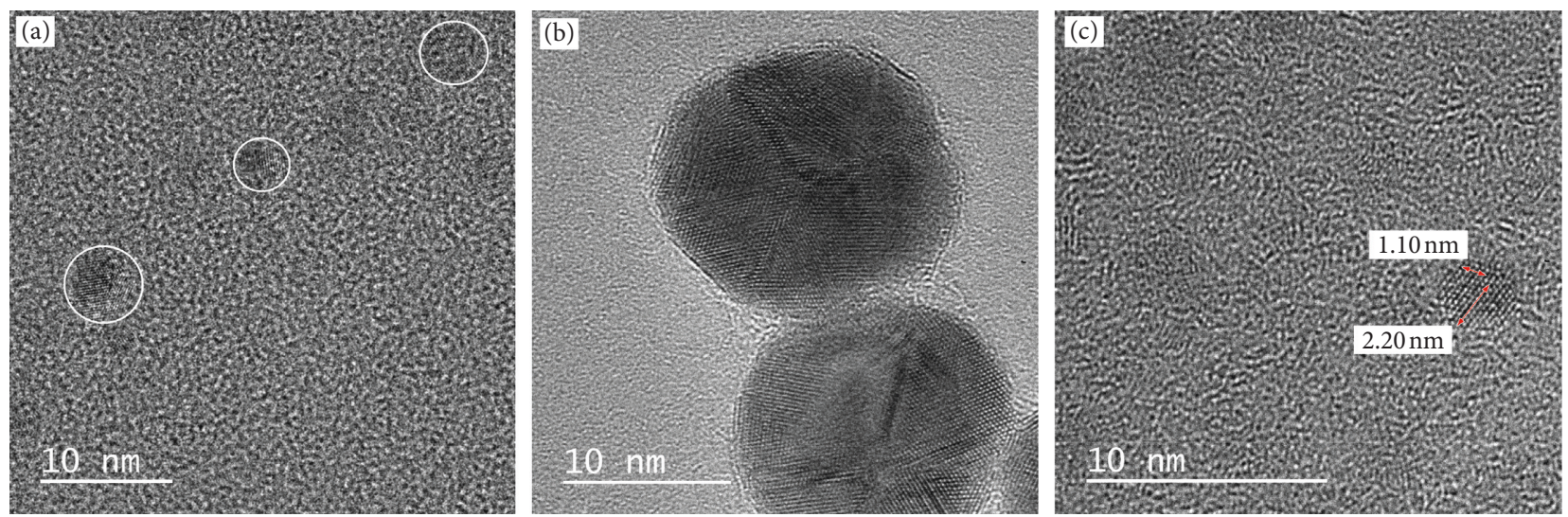

FIGURE 14: HR-TEM images recorded for the MnTTPCl/n-Au hybrid treated with $\beta$-carotene (a), the $n$ - $A u$ treated with $\beta$-carotene (b), and $\mathrm{MnTTPCl}$ treated with $\beta$-carotene (c).

3.4. STEM Images. STEM images recorded at small magnifications for the complex $M n T T P C l / n-A u$ exposed to $\beta$-carotene display large ovoidal structures with lacey edges (Figure 12). The same organization was previously reported for gold nanomaterials [42].

In comparison, STEM images for $\mathrm{MnTTPCl}$ after exposure to $\beta$-carotene (Figure 13) show smaller but wellshaped stellar-type structures that could further organize into more complex chain-like aggregates.

3.5. TEM Images. HR-TEM images obtained for $\mathrm{MnTTPCl} / n$ $A u$ hybrid treated with $\beta$-carotene (Figure 14(a)) as well as for $\mathrm{MnTTPCl}$ treated with $\beta$-carotene (Figure 14(c)) evidenced areas with specific crystalline organization. This phenomenon might be attributed to a deep change in structure and morphology of the metalloporphyrin due to axial ligation of the analyte. Measurements performed on the FTT corresponding to one such area indicated a spacing between crystal planes of $2.2 \AA$ (Figure 14(c)) and two families of crystal planes that intersect at angles less than 90 degrees.
HR-TEM images recorded for the gold colloid treated with $\beta$-carotene revealed spherical and quasispherical gold nanoparticles embedded in an amorphous layer, probably consisting of $\beta$-carotene (Figure 14(b)).

\section{Conclusions}

Vitamin A precursor ( $\beta$-carotene) has to be provided from diet or supplements, and the right amount of intake should be monitored. Encouraged by the multitude of analytical applications of manganese porphyrins for the detection of active biological molecules, we investigated a metallated porphyrin, chloro[5,10,15,20-tetrakis-(4-methylphenyl) porphyrinato manganese(III)], both alone and in complex with gold colloid for the detection of $\beta$-carotene.

It can be stated that the Mn-porphyrin and the hybrid gold nanomaterial are adequate and sensitive candidates for the optical detection of minute quantities of $\beta$-carotene, showing linear dependences in UV-Vis spectroscopy between the intensity of absorption and the $\beta$-carotene concentration. The best results are obtained using the 
$M n T T P C l / n$ - $A u$ hybrid. This material gives rise to the widest absorption band and is able to detect the largest $\beta$-carotene concentration interval: $9.80 \times 10^{-6}-1.15 \times 10^{-4} \mathrm{M}$. Electron transmission microscopy (HR-TEM) images obtained after treatment with $\beta$-carotene for both the $\mathrm{MnTTPCl}$ and $\mathrm{MnTTPCl} / n-\mathrm{Au}$ hybrid evidenced areas with specific crystalline organization, proving that a deep change in structure due to axial ligation of the analyte is taking place.

\section{Conflicts of Interest}

The authors declare that they have no conflicts of interest.

\section{Acknowledgments}

The authors acknowledge Romanian Academy (Institute of Chemistry Timisoara of Romanian Academy, Programme 3/2017) and UEFISCDI PNIII (Programme CorOxiPor 107PED/2017) for partial financial support.

\section{References}

[1] N. Zahra, A. Nisa, F. Arshad et al., "Comparative study of beta carotene determination by various methods: a review," Bio Bulletin, vol. 2, no. 1, pp. 96-106, 2016.

[2] S. Thunell, D. Andersson, P. Harper, A. Henrichson, Y. Floderus, and U. Lindh, "Effects of administration of antioxidants in acute intermittent porphyria," European Journal of Clinical Chemistry and Clinical Biochemistry, vol. 35, no. 6, pp. 427-33, 1997.

[3] S. Liu, U. Ajani, C. Chae, C. Hennekens, J. E. Buring, and J. E. Manson, "Long-term beta-carotene supplementation and risk of type 2 diabetes mellitus: a randomized controlled trial," JAMA, vol. 282, no. 11, pp. 1073-1075, 1999.

[4] Scientific Committee on Food Scientific Panel on Dietetic Products, Nutrition and Allergies, Tolerable Upper Intake Levels for Vitamins and Minerals, European Food Safety Authority, Parma, Italy, 2006, ISBN: 92-9199-014-0.

[5] J. Eicker, V. Kürten, S. Wild et al., "Betacarotene supplementation protects from photoaging-associated mitochondrial DNA mutation," Photochemical and Photobiological Sciences, vol. 2, no. 6, pp. 655-659, 2003.

[6] AREDS Report No. 8, "A randomized, placebo-controlled, clinical trial of high-dose supplementation with vitamins $\mathrm{C}$ and E, beta carotene, and zinc for age-related macular degeneration and vision loss," Archives of Ophthalmology, vol. 119, no. 10, pp. 1417-1436, 2001.

[7] M. Mozaffarieh, S. Sacu, and A. Wedrich, "The role of the carotenoids, lutein and zeaxanthin, in protecting against agerelated macular degeneration: a review based on controversial evidence," Nutrition Journal, vol. 2, p. 20, 2003.

[8] N. Aryaeian, M. Djalali, F. Shahram, S. Jazayeri, M. Chamari, and S. A. Nazari, "Beta-carotene, vitamin E, MDA, glutathione reductase and arylesterase activity levels in patients with active rheumatoid arthritis," Iranian Journal of Public Health, vol. 40, no. 2, pp. 102-109, 2011.

[9] P. Rust, I. Eichler, S. Renner, and I. Elmadfa, "Long-term oral beta-carotene supplementation in patients with cystic fibrosis-effects on antioxidative status and pulmonary function," Annals of Nutrition and Metabolism, vol. 44, no. 1, pp. 30-37, 2000.

[10] W. Stahl, U. Heinrich, H. Jungmann et al., "Increased dermal carotenoid levels assessed by noninvasive reflection spectrophotometry correlate with serum levels in women ingesting betatene," Journal of Nutrition, vol. 128, no. 5, pp. 903-907, 1998.

[11] B. J. Day, "Antioxidant therapeutics: Pandora's box," Free Radical Biology and Medicine, vol. 66, pp. 58-64, 2014.

[12] J. Dulińska, D. Gil, J. Zagajewski et al., "Different effect of beta-carotene on proliferation of prostate cancer cells," Biochimica et Biophysica Acta (BBA)-Molecular Basis of Disease, vol. 1740, no. 2, pp. 189-201, 2005.

[13] J. M. Gaziano and C. H. Hennekens, "The role of betacarotene in the prevention of cardiovascular disease," $A n$ nals of the New York Academy of Sciences, vol. 691, no. 1, pp. 148-155, 1993.

[14] B. Poljsak, "Strategies for reducing or preventing the generation of oxidative stress," Oxidative Medicine and Cellular Longevity, vol. 2011, Article ID 194586, 15 pages, 2011.

[15] R. Rahiman, M. A. M. Ali, and M. S. Ab-Rahman, "Carotenoids concentration detection investigation: a review of current status and future trend," International Journal of Bioscience, Biochemistry and Bioinformatics, vol. 3, no. 5, pp. 466-472, 2013.

[16] H. Shintani, "HPLC analysis of vitamin A and carotenoids," Pharmaceutica Analytica Acta, vol. 4, no. 3, p. 218, 2013.

[17] B. Zhao, S.-Y. Tham, J. Lu, M. H. Lai, L. K. H. Lee, and S. M. Moochhala, "Simultaneous determination of vitamins C, $\mathrm{E}$ and $\beta$-carotene in human plasma by high-performance liquid chromatography with photodiode-array detection," Journal of Pharmacy and Pharmaceutical Sciences, vol. 7, no. 2, pp. 200-204, 2004.

[18] A. L. Sowell, D. L. Huff, P. R. Yeager, S. P. Caudill, and E. W. Gunter, "Retinol, alpha-tocopherol, lutein/zeaxanthin, beta-cryptoxanthin, lycopene, alpha-carotene, trans-betacarotene, and four retinyl esters in serum determined simultaneously by reversed-phase HPLC with multiwavelength detection," Clinical Chemistry, vol. 40, no. 3, pp. 411-416, 1994.

[19] H. M. Pinheiro-Santana, P. C. Stringheta, S. C. C. Brandão, H. H. Páez, and V. M. V. de Queiróz, "Evaluation of total carotenoids, $\alpha$ - and $\beta$-carotene in carrots (Daucus carota L.) during home processing," Food Science and Technology, vol. 18, no. 1, pp. 39-44, 1998.

[20] G. L. Radu, S. C. Litescu, C. Albu, E. Teodor, and G. Truica, "Beta-carotene and lycopene determination in new enriched bakery products by HPLC-DAD method," Romanian Biotechnological Letters, vol. 17, no. 1, pp. 7005-7012, 2012.

[21] E. Souri, H. Jalalizadeh, H. Farsam, H. Rezwani, and M. Amanlou, "Simultaneous determination of anthocyanoside and beta-carotene by third-derivative ultraviolet spectrophotometry," DARU Journal of Pharmaceutical Sciences, vol. 13, no. 1, pp. 11-16, 2005.

[22] I. V. Ermakov, M. R. Ermakova, W. Gellermanna, and J. Lademann, "Noninvasive selective detection of lycopene and beta-carotene in human skin using Raman spectroscopy," Journal of Biomedical Optics, vol. 9, no. 2, pp. 332-338, 2004.

[23] M. E. Darvin, I. Gersonde, M. Meinke, W. Sterry, and J. Lademann, "Non-invasive in vivo determination of the carotenoids beta-carotene and lycopene concentrations in the human skin using the Raman spectroscopic method," Journal of Physics D: Applied Physics, vol. 38, no. 15, pp. 2696-2700, 2005.

[24] K. Kushwaha, J. Saxena, B. K. Tripathi, and M. K. Agarwal, "Detection of carotenoids in psychrotrophic bacteria by spectroscopic approach," Journal of BioScience and Biotechnology, vol. 3, no. 3, pp. 253-260, 2014. 
[25] A. I. Alajtal, H. G. M. Edwards, and M. A. Elbagermi, "Vibrational spectroscopic identification of beta-carotene in usnic acid and PAHs as a potential Martian analogue," International Journal of Chemical, Molecular, Nuclear, Materials and Metallurgical Engineering, vol. 8, no. 1, pp. 50-53, 2014.

[26] A.-M. Iordache, R. Cristescu, E. Fagadar-Cosma et al., "Histamine detection using functionalized porphyrin as electrochemical mediator," Comptes Rendus Chimie, vol. 21, no. 3-4, pp. 270-276, 2018.

[27] S. Iordache, R. Cristescu, A. C. Popescu et al., "Functionalized porphyrin conjugate thin films deposited by matrix assisted pulsed laser evaporation," Applied Surface Science, vol. 278, pp. 207-210, 2013.

[28] M. C. Gallo, B. M. Pires, K. C. F. Toledo et al., "The use of modified electrodes by hybrid systems gold nanoparticles/ Mn-porphyrin in electrochemical detection of cysteine," Synthetic Metals, vol. 198, pp. 335-339, 2014.

[29] Y. Zhao, M. Sun, W. Ma, H. Kuang, and C. Xu, "Biological molecules-governed plasmonic nanoparticle dimers with tailored optical behaviors," Journal of Physical Chemistry Letters, vol. 8, no. 22, pp. 5633-5642, 2017.

[30] I. Sebarchievici, B. O. Tăranu, M. Birdeanu, S. F. Rus, and E. Făgădar-Cosma, "Electrocatalytic behavior and application of manganese porphyrin/gold nanoparticle-surface modified glassy carbon electrodes," Applied Surface Science, vol. 390, pp. 131-140, 2016.

[31] E. Fagadar-Cosma, I. Sebarchievici, A. Lascu et al., "Optical and electrochemical behavior of new nano-sized complexes based on gold-colloid and Co-porphyrin derivative in the presence of $\mathrm{H}_{2} \mathrm{O}_{2}$," Journal of Alloys and Compounds, vol. 686, pp. 896-904, 2016.

[32] I. Sebarchievici, A. Lascu, G. Fagadar-Cosma et al., "Optical and electrochemical mediated detection of ascorbic acid using manganese porphyrin and its gold hybrids," Comptes Rendus Chimie, vol. 21, no. 3-4, pp. 327-338, 2018.

[33] E. Fagadar-Cosma, C. Enache, I. Armeanu et al., "The influence of $\mathrm{pH}$ over topography and spectroscopic properties of silica hybrid materials embedding meso-tetratolylporphyrin," Materials Research Bulletin, vol. 44, no. 2, pp. 426431, 2009.

[34] A. D. Adler, F. R. Longo, F. Kampas, and J. Kim, "On the preparation of metalloporphyrins," Journal of Inorganic and Nuclear Chemistry, vol. 32, no. 7, pp. 2443-2445, 1970.

[35] I. Creanga, A. Palade, A. Lascu, M. Birdeanu, G. FagadarCosma, and E. Fagadar-Cosma, "Manganese(III) porphyrin sensitive to $\mathrm{H}_{2} \mathrm{O}_{2}$ detection," Digest Journal of Nanomaterials and Biostructures, vol. 10, no. 1, pp. 315-321, 2015.

[36] A. Lascu, A. Palade, G. Fagadar-Cosma et al., "Mesoporous manganese-porphyrin-silica hybrid nanomaterial sensitive to $\mathrm{H}_{2} \mathrm{O}_{2}$ fluorescent detection," Materials Research Bulletin, vol. 74, pp. 325-332, 2016.

[37] P. Muthukumar and S. Abraham John, "Gold nanoparticles decorated on cobalt porphyrin-modified glassy carbon electrode for the sensitive determination of nitrite ion," Journal of Colloid and Interface Science, vol. 421, pp. 78-84, 2014.

[38] E. Fagadar-Cosma, A. Lascu, A. Palade, I. Creanga, G. Fagadar-Cosma, and M. Birdeanu, "Hybrid material based on 5-(4-pyridyl)-10,15,20-tris(4-phenoxyphenyl)-porphyrin and gold colloid for $\mathrm{CO}_{2}$ detection," Digest Journal of Nanomaterials and Biostructures, vol. 11, no. 2, pp. 419-424, 2016.

[39] J. Kesters, P. Verstappen, M. Kelchtermans, L. Lutsen, D. Vanderzande, and W. Maes, "Porphyrin-based bulk heterojunction organic photovoltaics: the rise of the colors of life," Advanced Energy Materials, vol. 5, no. 13, p. 1500218, 2015.

[40] A. M. Askhabov and N. P. Yushkin, "The kvataron mechanism responsible for the genesis of noncrystalline forms of nanostructures," Doklady Earth Science, vol. 368, no. 7, pp. 940-942, 1999.

[41] A. Sanchez-Iglesias, I. Pastoriza-Santos, J. Perez-Juste, B. Rodriguez-Gonzalez, F. J. Garcia de Abajo, and L. M. LizMarzan, "Synthesis and optical properties of gold nanodecahedra with size control," Advanced Materials, vol. 18, no. 19, pp. 2529-2534, 2006.

[42] J. Reguera, D. Jiménez de Aberasturi, M. Henriksen-Lacey et al., "Janus plasmonic-magnetic gold-iron oxide nanoparticles as contrast agents for multimodal imaging," Nanoscale, vol. 9, no. 27, pp. 9467-9480, 2017. 

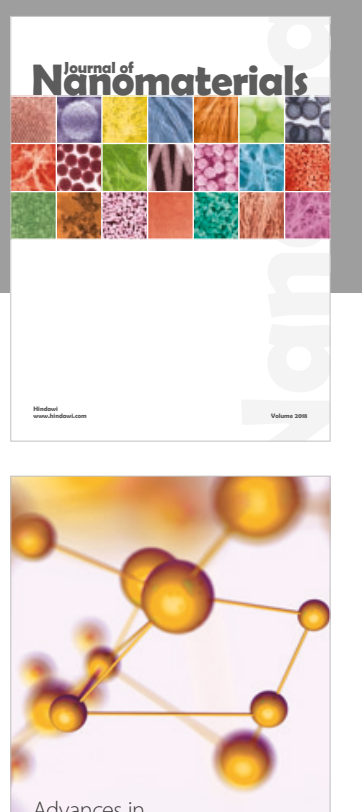

Physical Chemistry
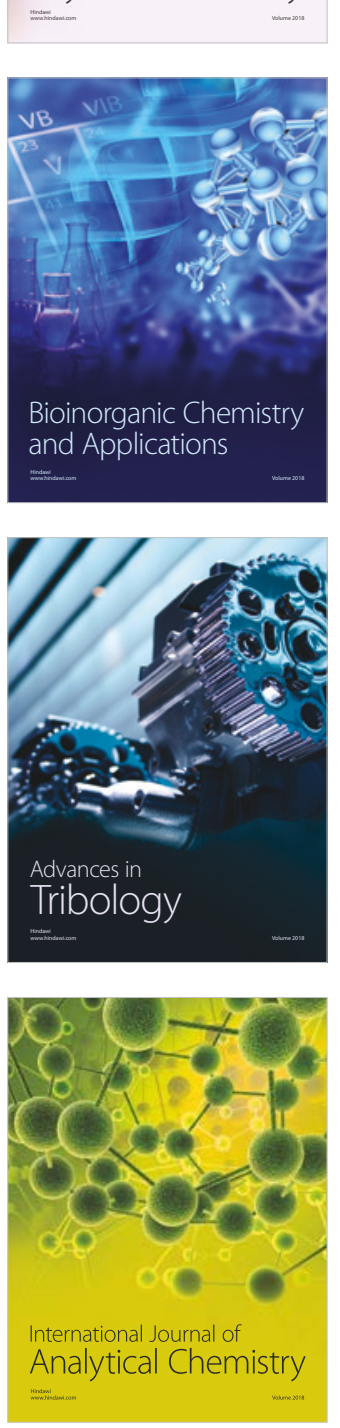

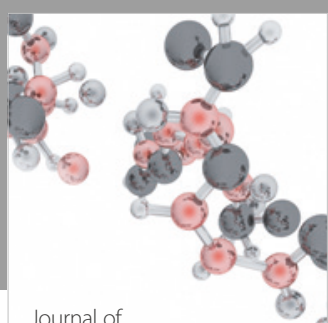

Analytical Methods

in Chemistry

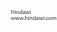

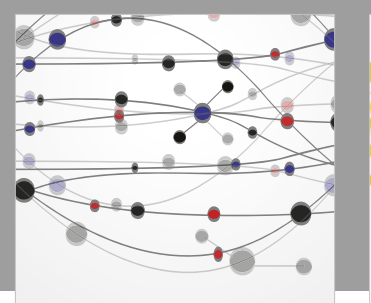

The Scientific World Journal

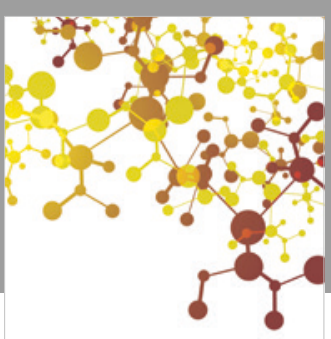

Journal of

Applied Chemistry
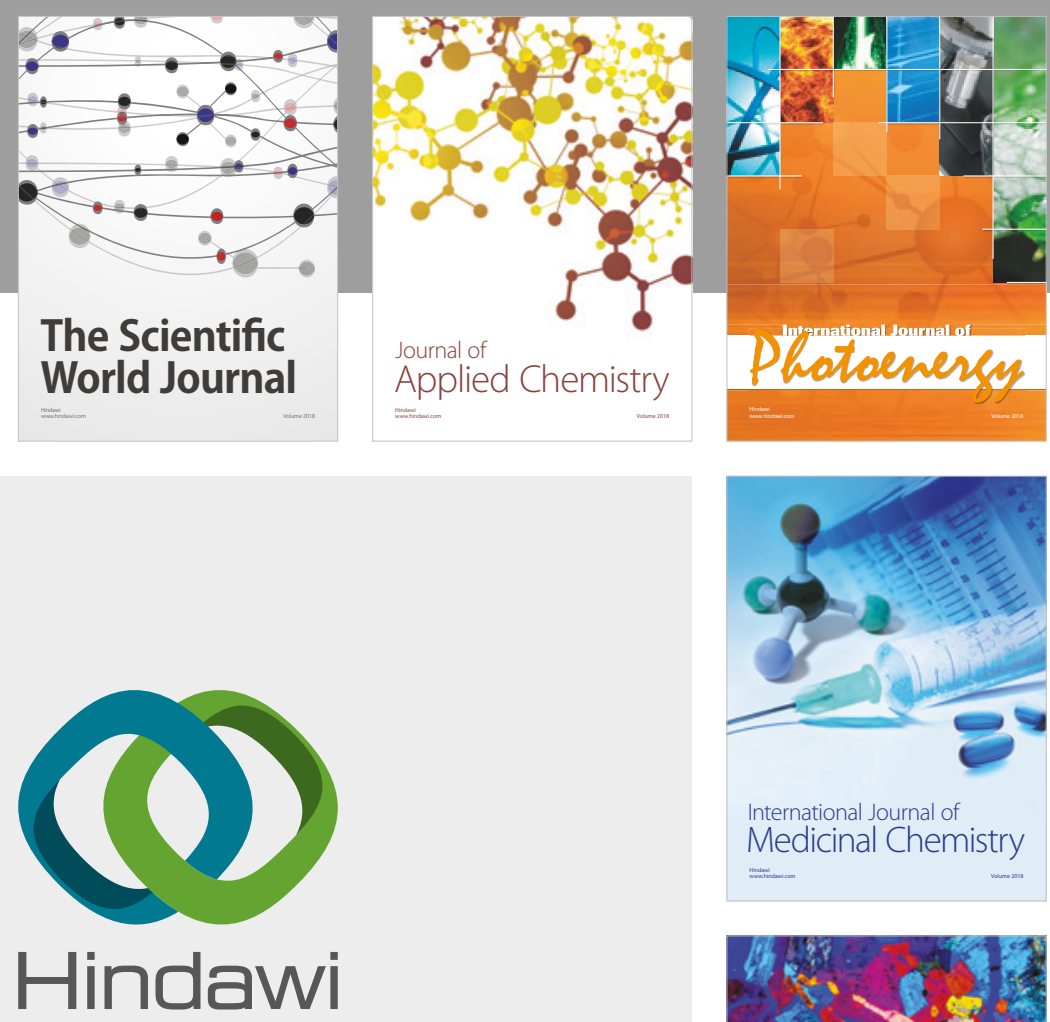

Submit your manuscripts at

www.hindawi.com
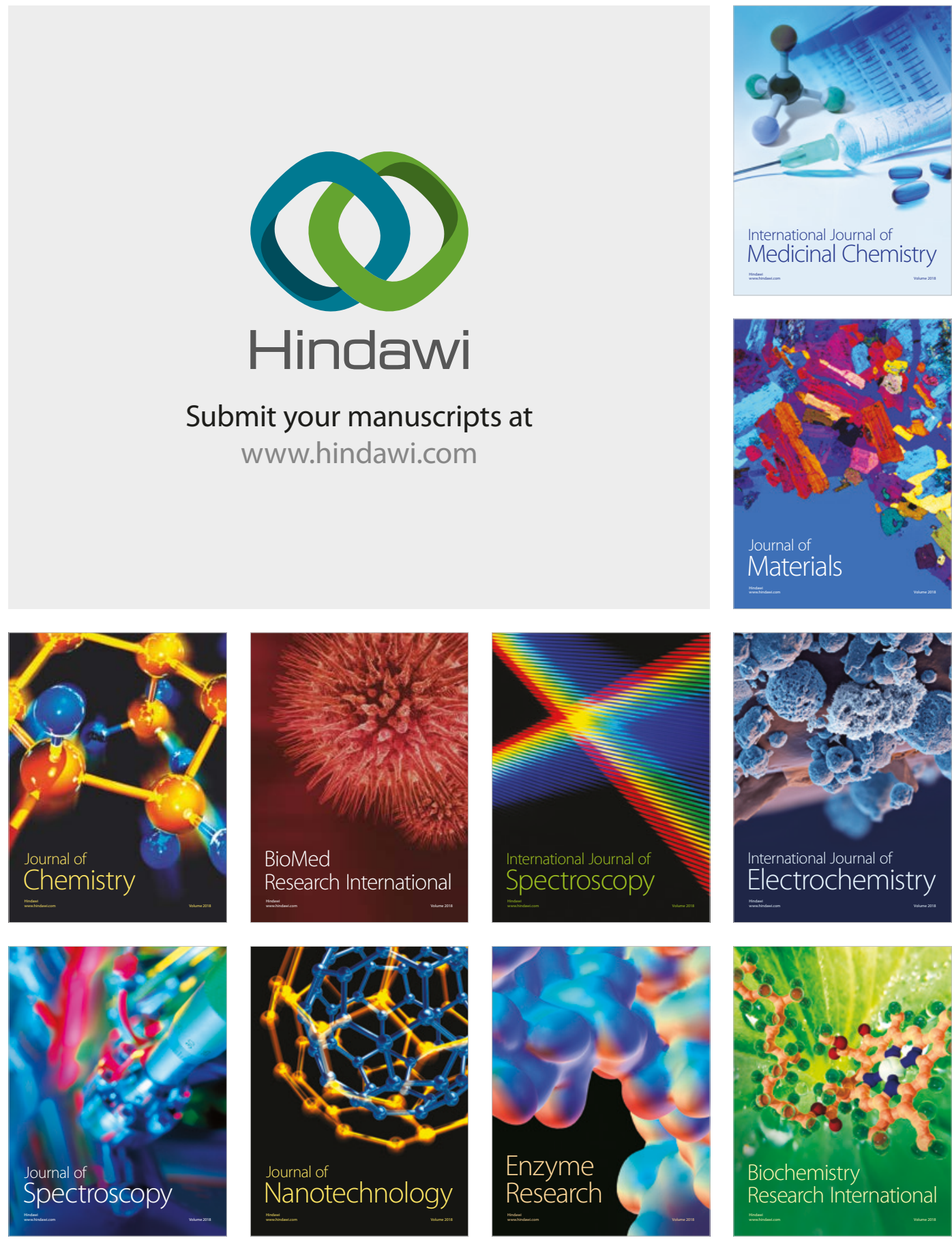
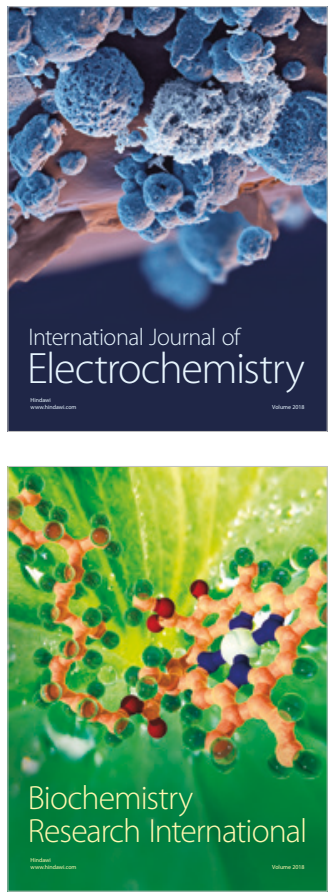